\title{
DISCUSSION ON THE TERMS OF IDEA MANAGAMENT AND IDEA MANAGAMENT SYSTEMS
}

\author{
ELĪNA MikeLSONE ${ }^{1}$, Elita LieLA ${ }^{2}$ \\ BA School of Business and Finance (Latvia)
}

\begin{abstract}
Although idea management (IM) and idea management systems (IMS) and related topics have been researched since 1982 and IM itself is as old as the first ideas, authors in previous research specified 18 research gaps in literature about IM and one of the most important that there is no united view on the terms IM and IMS and there are no specialized researches about these terms, as well, in the literature of IM they are not board discussed. Purpose of the research is to discuss and create definitions of terms IM and IMS using the reviewed literature. Research object: literature on IM and IMS. Research subject: terms of IM and IMS. Main research method - literature review. Data collected from 70 sources, including scientific publications, conference proceedings, books, white papers etc. published over the last 33 years, i.e., from January 1982 to February 2015, in all research fields. The research highlights that in the literature there are wide variety of the definitions of terms IM and IMS. The results of the research revealed that definitions of IM have not fundamentally changed over the time, but the definitions of IMS have transformed from "passive" to "active" IMS in millennium. The object of these definitions more often are described as systematic and manageable. Results probe that IM could be defined as - systematic, manageable process of idea generation, evaluation and development, but the IMS as a tool, tool kit or complex system which provides systematic, manageable process of idea generation, evaluation and development. The intensity of IM and IMS researches varies by region, but there are no major regional differences in defying the terms.
\end{abstract}

KEYWORDS: Idea management, Idea management systems, Discussion, Literature review.

JEL CODE: M190; M150; M110

\section{Introduction}

Innovation is a very extensive concept. It can involve patents, inventions or methods, but basically every new introduced idea is an innovation, so ideas constitute as the raw material for innovation and idea management can be seen as the core of innovation (Bothos, Apostolou, Mentzas, 2012). Some researchers (Nillson, Elg, Bergman, 2002) reveals that idea management system (IMS) used in organization strengthens innovation capacity, and several researchers (Khurana, Rosenthal, 1998; Day, Gold, Kuczmarski, 1994; Zhang, Doll, 2001) had pointed that there is an opportunity to improve innovation through managing improvements in the front-end innovation, including idea management (IM). That proves that IM is like the main engine

1 Elina Mikelsone - PhD student at BA School of Business and Finance. Scientific interests: idea management, virtual idea management products and innovation management

E-mail: mikelsone.elina@gmail.com

Phone: +37126418258

2 Elita Liela - Programme Director at BA School of Business and Finance, Riga, Latvia. Scientific interests: risk management and innovation policy

E-mail: elita.liela@ba.lv

Phone: +371 67324002 
of innovation development. According to Global Innovation Index where 143 countries are included, Latvia is placed 34, Lithuania 39, Estonia 24 (INSEAD, 2014), and such placing revels that Baltic States need to increase innovation level and one of the first steps is to improve IM process. Important pillar in IM improvement is comprehension of the terms, because it is important to understand what the object is and what kind of characteristics it have. Authors also will revealed the regional identity aspects about IM and IMS, according to theoretical research about applied terms in the region.

Although idea management (IM) and idea management systems (IMS) and related topics have been researched since 1982 and IM itself is as old as the first ideas, authors in previous research (Mikelsone, Lielā, 2015) specified 18 research gaps in literature about IM and one of the most important that there is no united view on the terms IM and IMS, and there are no specialized researches about these terms, as well, in the literature of IM they are not board discussed. In the research conducted in February 2015, authors suggested that there should be additional research and discussion on the definition of IM and IMS to create common view on these terms.

Purpose of the research is on the basis of IM literature review to discuss and create definitions of terms IM and IMS.

Research object: literature on IM and IMS. Research subject: terms of IM and IMS.

Tasks:

- to manage research in scientific databases to find literature where IM is mentioned and to analyse terms of IM and IMS from selected sources analysing:

- terms and their evolution;

- regional identity aspects;

- relation between terms;

- focus on the term object (systematic/non-systematic, manageable/non-manageable).

- to develop common definitions on these terms.

Research is based on literature review. More about methodology in section 1.

There are numerous literature sources with a modest research of terms IM and IMS, but there is a lack of specialized and deep reviews about these terms. Novelty of this paper is that it is first specialized research about the terms of IM and IMS. Previous there have been only 3 researches (Mikelsone, Lielā, 2015; Rose, Jensen, 2012; Sadriev, Pratchenko, 2014) about literature concerning IM, IMS and history of them, but none of the researches terms IM and IMS are discussed and researched deeply.

\section{Research methodology and collected set of data}

Research is based on literature review. Research is divided in 4 stages: (1) research in 7 scientific databases - search for the literature where "idea management" is mentioned; (2) to select literature directly about IM and IMS; (3) to exclude duplicates; (4) to analyse terms of the IM and IMS in selected literature.

Search for the literature sources in the databases is not restricted to definite academic field, because IM could be researched not only in innovation management context but in information technology literature as well.

Results analysed in several dimensions: (1) terms and their evolution; (2) regional identity aspects; (3) relation between terms; (4) focus on the term object (systematic/non-systematic, manageable/non-manageable).

Three research stages had been developed:

1) First stage included the search of the literature sources where "idea management" is mentioned. In this stage 4283216 literature sources were found.

2) Second stage excluded all sources that are not connected with IM or are not mentioning definitions of IM, IMS.

3) Third stage excluded duplicated sources. 
4) Fourth stage summarized 45 unique definitions of IM and 41 of IMS. Detailed literature source count in different stages is reflected in Table 1.

Table 1. Data set collection stages and count of sources

$\begin{array}{lllll} & \begin{array}{l}\text { Stage 1 } \\ \text { Sources mentioned } \\ \text { "idea management" }\end{array} & \begin{array}{l}\text { Stage 2 } \\ \text { Sources about idea management } \\ \text { with mentioned IM; IMS } \\ \text { definitions }\end{array} & \begin{array}{l}\text { Stage 3 } \\ \text { Unique sources }\end{array} & \begin{array}{l}\text { Stage 4 } \\ \text { Unique term } \\ \text { definitions/ } \\ \text { applications }\end{array} \\ \text { Scopus } & 36237 & 15 & 70 & \text { IM-45 } \\ \text { ScienceDirect } & 396435 & 2 & \text { IMS-41 } \\ \text { Google Scholar } & 3720000 & 28 & \\ \text { Sage Journals } & 137624 & 7 & & \\ \text { Ebsco Academic } & 996 & 5 & & \\ \text { Search Complete } & & 3 & & \\ \text { Emerald } & 101685 & 49 & & \\ \text { Web of Science } & 239 & 109 & \\ \text { Sum: } & 4393216 & & \end{array}$

Source: compiled by the authors

The methodology in this research is improved (adding stage 4) compared to author's previous research about literature review, adding the fourth stage - selection of unique term definitions/applications. In the end authors conclude that data set in do not differ significantly - only 1 source in the stage 3 . The previous methodology was used in February, but this research was conducted in April.

\section{Discussion on the terms of IM and IMS}

In this section will discuss terms of IM and IMS in several dimensions: (1) terms and their evolution; (2) focus on the term object (systematic/non-systematic, manageable / non-manageable); (3) relation between terms; (4) regional identity aspects. The aim of this section is to discuss terms of IM and IMS and in the end to create definition (based on term application and definition evaluation and determination of focuses on the term object (systematic/non-systematic, manageable/non-manageable). Created definitions in the subsection 2.4 .

\subsection{Discussion on IM}

The first literature source that mentioned idea management is from 1982 (Galbraith, 1982) and in it the term IM was used on individual level as cognitive and social process, but only one year later Green, Bean and Snavely (1983) has noticed that idea flow process enclose idea generation, capture, retention, retrieval of ideas. These applications of terms are confronting, but authors conclude that both applications are appropriate, because IM could be characterized not only as organizational process, but also as private and social process. Authors would like to mark that in all researched literature sources IM and IMS terms are applied to characterise IM and IMS with human as main idea generator, but authors conclude that it is not impossible that ideas could be generated also by the artificial intelligence (AI) as concluded in many researches, for example, Boden has revealed that: "AI techniques can be used to create new ideas in three ways: by producing novel combinations of familiar ideas; by exploring the potential of conceptual spaces; and by making transformations that enable the generation of previously impossible ideas" (Boden, 1998: 347). For example, Moss et al. (2011) in the study report that the aim of IMS is to support human generated idea management to increase innovation capacity, so showing that there are also other kind of idea generators possible.

Applegate (1986) stressed out that IM is decision support system with focus on brainstorming. Also Bjork and Magnusson (2009) has focused on IM as ideation, but according to many other definitions and 
applications of the term IM, it consists not only from idea generation stage. For example, Bothos, Apostolou and Mentzas (2008) stressed out that IM consist of 3 main parts- idea generation, idea enhancement, idea evaluation. Idea evaluation phase in IM process is often mentioned as part of IM process but idea enhancement is not, authors suppose that this is because this part is frequently connected with idea generation process, where idea generation could have more than one round and in this process ideas could be enhanced. About more complex idea improvement rounds in IM process talks Lu and Mantei (1991) educed that IM processes- agree and add on to the suggested idea, agree and subdivide the suggested idea, modify the suggested idea, modify preserve the suggested idea, scratch and restart, suspend and wait, agree and wait, compare and consolidate, deprivatize idea. Authors suppose that described IM process is detailed but all processes could be divided in 3 main groups- idea generation, evaluation and development. Furthermore Rowbotham and Bohlin has created complex IM process description with many stages - "development of criteria, preparation for brainstorming session, screening meeting, workshop to evolve ideas and initial ranking, brief investigation of ideas, rank and document concepts" (Rowbotham, Bohlin, 1996: 1). Also these stages could be divided in idea generation, evaluation and development, but this concept has emphasis that idea generation process could consist not only from practical idea generation, but also preparation process for idea generation which includes also development of criteria.

Azrolan and Pavlin (1998) accented that IM is idea generation and idea conversation in products also Karanjikar (2007) emphasized that IM is generation of product ideas, screening and execution of these ideas. Authors would like to notice that IM is not only about one type of ideas management, because IM is universal process which could be applied to manage a lot of different types of ideas. This idea also declared in some definitions of the term, for example, Bettoni et al. (2010) explained that before idea finding, idea structuring, evaluation, selection comes creative frustration, problem analysis and tasks definition. That emphasis that IM process starts with problem analysis and definition of tasks (idea generation, idea generation preparation phase) or in other words with definition of the aim of IM or what kind of ideas would be promoted. Idea generation preparation phase has also been recognized by other authors as an important part of IM, for example, Flynn et al. (2003) defined IM as strategic directions, environment scanning, opportunity identification, idea generation, also Lindross (2006) has described opportunity identification as IM process part, but Barczak, Griffin and Kahn (2009) called this process - idea preparing.

There are some sources where IM is connected only with ideas made by employees inside organizations, for example, Bassiti and Ajhoun revealed that IM is the front-end part of the innovation process capturing ideas from employees and then evaluating, study emphases that IM is "based essentially on the generation of new concepts, by combining organizations knowledge and collective intelligence, aligned by the organizations contextual factors" (Bassiti, Ajhoun, 2013: 551). Also Deichmann (2012), Dickinson (1932), Fairbank and Williams (2001), Reuter (1997), Van Dijk and Van den Ende (2002) in the studies admitted that aim of IM is to stimulate, support and channel employee ideas. Authors of the research would like to admit that IM is not restricted to some limited idea sources or idea managers (idea generators, evaluators).

Gish (2011) described IM as idea promotion, but Klein and Lechner (2010) as idea competition which includes idea generation and evaluation. Authors compare that idea promotion is more comprehensive description for IM that idea competition, because IM do not end after generation and evaluation of ideas as describes Summa (2004) after idea gathering, evaluation, takes place development and following rewarding of ideas Authors has researched that development of ideas is mentioned in the majority of researched term definitions and applications, but following rewarding is declared only in some, for example, in Wood (2003) study. Authors consider that rewarding process could be seen as a part of idea development process.

The majority terms of used to define IM have the fundamentally the same bases, that IM is a process which includes generation and evaluation of ideas, but there are some additional features described in some of terms, for example, Couglan and Johnson (2008) declared idea communicating stage, but Saatcioglu (2002) - seeking of ideas and realization of ideas, Fritz (2002) - storage of ideas, Sandstrom and Bjork 
(2010) - selection of ideas, Shani and Divyapriya (2011) - distribution of ideas, Bakker, Boersma, Oreel (2006) - selling and funding of ideas, Boeddrich (2004) - adoption, clustering, screening, selection, improvement of ideas. But idea generation and evaluation, as describes, for example, Selart and Johansen (2011) do not fully describes IM process. There are some detailed IM term description, for example, Brem and Voigt (2009) described IM as idea collecting/idea creating, idea profile, sifting, classifying, enriching, improving, rating, documentation, sifting classifying, implementation or simply efficient idea generation, evaluation and selection and implementation.

Aagaard (2012) has emphased that IM is idea development process management- defining from strategically aspect, environment scanning, idea creation and collection, evaluation, selection and project / concept development, but Lower and Heller (2014) provided more technical sight on IM that in this process consist of autonom databases and data models . Authors conclude that both terms are describing one phenomenon - from practical and technical perspectives, but the main idea is that IM consists of idea collection and promotion.

Iversen et al. (2009) had described IM as process circle - inspire and involve, generate and capture, develop and enrich, evaluate and select, but the authors have improved this model adding implementation, post-implementation learning and feedback - according to desired outcome processes. Authors positively regard this definition, because it describe IM as circular process, but it should be noticed that every part of the process could be star and the end of process.

In many studies (Vagn, Clause, Gish, 2013; Miecznik, 2013; Bassiti, Griffin, Kahn, 2013; Voigt, Brem, 2006; Summa, 2004; Aagaard, 2012; Brem, Voigt, 2007; 2009; Bothos, Apostoulou, Mentzas, 2012; Glassmann, 2009) has noticed that IM is part of innovation as front-end innovation process. Summa (2004) highlights that it not only connected with innovation but also closely linked to various activities such as knowledge management and business intelligence. Authors conclude that IM is part of innovation process and is closely linked with various activities and aspects which occurs in / out organizations.

Authors had made the additional research data in databases - Google Scholar (2015) and Scopus (2015) - to reveal the most influential authors in IM and IMS literature. Results of the research represents that the most cited authors about idea management are Bothos, Westerski, Brem, Flynn, Vandenbosch, Sandstrom. Vandenbosh, Saatcioglu and Fay (2006) definite IM as process of recognizing the need for ideas, generating and evaluating them. It is revealed that Vandenbosh, Saatcioglu and Fay created IM definition is the most frequent used IMD definition in the researched sources, it has used in many analysed literature sources, for example, studies of Vagn, Clause and Gish (2013), Bothos, Apostoulou and Mentzas (2012) Deichmann (2012). Researching all term IM and IMS definitions it's concluded that Vandenbosh et al. created definition is the most influential term, because the most of IM and IMS fundamentally is based on Vandebosh, Saatcioglu and Fay (2006) created definition of IM. Authors suggest that additional research should be conducted (research based in literature review of cited sources) to research more deeply the most influential literature sources on IM and IMS definition creation.

Authors have created additional research to find out the most frequent used words in IM definitions. The most frequent used words in IM definitions are idea, process, generation, evaluation, development, selection. Authors conclude that these are the main characteristic words of IM definition and should be included in new-developed definition. Authors also created "Word cloud" which reflects the most frequent used terms (largest size, more frequent used). "Word cloud" developed using internet platform www.wordle.net, were all of researched IM and IMS definitions were used to create the visualization of most frequent used terms in these definitions. "Word cloud" see in Figure 1. 


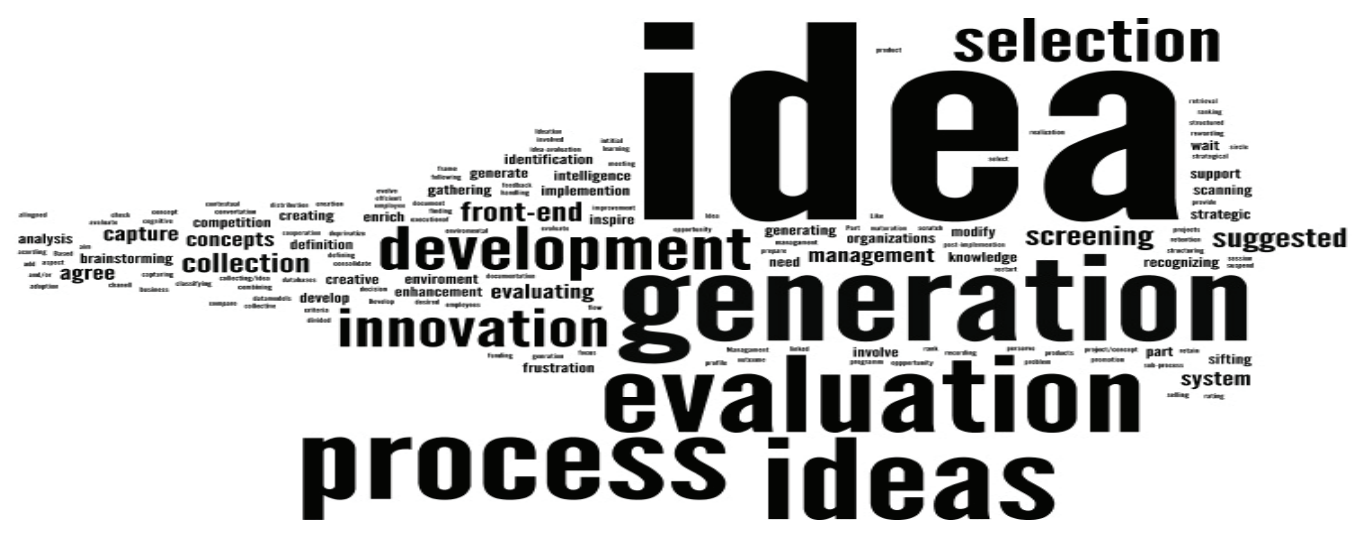

Figure 1. Most frequent used terms in IM definitions

Source: compiled by the authors

Based on the research on term IM authors had conclude that the term don't change fundamentally in different sources. IM could be definite as process of idea generation, evaluation and development. But over the time there are some aspects emphasized in definitions as rewarding process, business intelligence, idea storage and communication etc. The authors developed fundamental IM term depiction (with added sub processes) see in Figure 2.

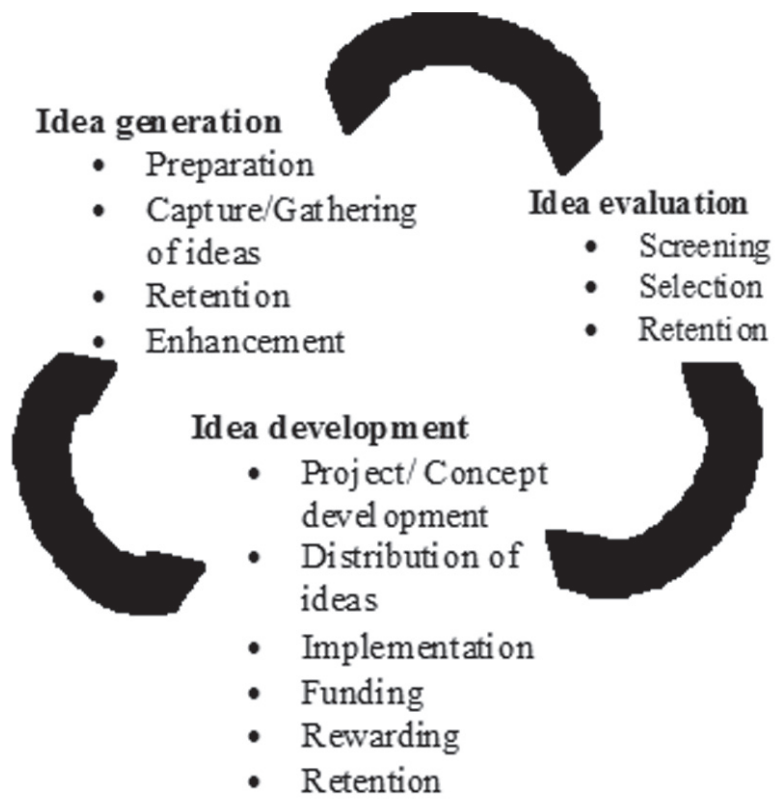

Figure 2. IM term depiction

Source: compiled by the authors

\subsection{Discussion on IMS}

Authors have researched evolution of IMS and has conclude that IMS could be divided in two groupspassive and active IMS.

Passive IMS according to Brem, Voigt (2007) and Van Dijk, Van den Ende (2002) could be called suggestion systems which prefers extraction of ideas, idea identification, idea flow-up, but Westerski, Dalamagas, Iglesias (2013) calls it suggestion boxes, but also revealed that these are less sophisticated systems than active. Gamlin, Yourd and Patric (2007) named passive IMS as classical IMS and manifested that in these 
IMS employees are encouraged to submit any idea that comes to mind, but unfocused also Brem and Voigt (2007) determined that the aim of this system is to harness employees' creativity. That reveals that the main idea sources in passive IMS are internal. According to Brem, Voigt and Conert, Schenk "it is an instrument for business-wide advancements and improvements, helping with the creation of ideas and innovation" (Conert, Schenk, 2000: 65), but according to Brinkman and Heidack suggestion system "in its ideal form, the suggestion system is to be seen as a device for the advancement and utilization of the creativity of all persons involved in an organization" (Brinkman, Heidack, 1984: 32; Brem, Voigt, 2007: 306). Authors conclude the main aim of passive IMS is to utilize creativity to improve innovation in a simple and unfocussed process.

According to Robinson (1997) passive IMS frequently is more advanced than a simple advice and recommendation mailbox, but it could be also a real life activities, for example, simple idea submission boxes or idea submission to managers. According to Gamlin, Yourd and Patrikc (2007) Such system allows to submit ideas regarding variety of themes and questions, but there is an ongoing tendency for quality and quantity of ideas decline after the implementation of idea, and the submitted ideas often fall short in terms of conformity with what is expected from the organizers. Such aspects make the process more inefficient. In such type of IMS ideas are not focused and there is an ongoing problem to find the right solution and application for them in company that organized the sourcing. For these reasons passive IMS became less popular with the emergence of active IMS (Miķelsone, 2013).

Authors has inspired to create IMS classification from Gamlin, Yourd and Patrick (2007). It was the first study with used term of active IMS. In this paper authors has described active IMS-Imaginatik's. This system has more sophisticated features than passive IMS, for example, submission form, searchable database, feedback mechanism, scoring / evaluation mechanism, incentive mechanism to encourage use and acceptance, interactive mechanisms to build and comment on ideas and support collaboration, a routing mechanism to collect input from subject matter experts.

Bothos, Apostolou and Mentzas (2009) revealed that active IMS is utilized system for idea management, but Westerski, Iglesias and Rico (2010) that it provides tools that will enable to assess the collected ideas and select the best ones for implementation and Tung, Yuan and Tsai (2009) that it consist of 4 modules - ideation module, competition module, mutation module, monitoring module. Based on the research authors conclude that IMS is tool, tool kit, complex system which main features are generation, evaluation and development of ideas. In the literature are mentioned a lot of additional features, for example, Nilsson, Elg and Bergman (2002) declared that IMS functionalities are storing of ideas, Poveda, Westerski and Iglesias (2012) - organizing and seeking of ideas, Hrastinski et al. (2010) - discussing of ideas openly or within predefined categories, Bailey and Horvitz (2010) - encouraging of community ideation on defined business problems through submitting, discussing, scoring and disseminating ideas, among other functions, Goyal and Sampath (2007) - filtering, aligning, approving, implementing of ideas, Shani and Divyapriya (2011) - exploiting and measuring ideas Authors conclude that the main functionalities of IMS are generation, evaluation and development of ideas, but if necessary additional functionalities can be integrated.

In active IMS organizations defines the questions and problems, to whom the ideas are created and developed. Furthermore Xie and Zhang (2010) also has described active IMS as more complex system with 3 main functions - creative idea recognition, idea selection, idea evaluation and visualization. There's also an option to include others (outside the previously defined group) in the process of evaluation to create a more representative rating of ideas (Gamlin, Yourd, Patrick, 2007). Deichmann (2012), Jensen et al. (2007) considered IMS "under the umbrella of high-performance human resource practises that are aimed at achieving organizational excellence through increasing employee involvement" (Deichmann, 2012: 15; Jensen et al., 2007: 685). Authors would like to conclude that active IMS could involve not only internal sources of ideas, but also external. Board range of idea generators is manifested by Westerski and Iglesias (2012) declaring that IMS: "Notion of crowdsourcing is employed by inviting customers or employees to share and collaboratively improve their ideas" (Westerski, Iglesias, 2012: 1). According to Westerski, Dalamagas, Iglesias (2013) and Westerski, Iglesias, Nagle (2011) during the last decade of IMS evolution "IMS have extended their coverage from collecting ideas from large communities via computer networks to collabora- 
tive improvement of those ideas, the assessment of ideas and IM in synergy with other enterprise processes" (Westerski, Iglesias, Dalamagas, 2013: 1316; Westerski, Iglesias, Nagle, 2011: 493). Description of both IMS types see in the Table 2.

Table 2. IMS history

\begin{tabular}{|c|c|c|c|c|}
\hline $\begin{array}{c}\text { Period of } \\
\text { domination }\end{array}$ & Title & $\begin{array}{c}\text { Specific used } \\
\text { titles in literature }\end{array}$ & & Characteristics \\
\hline \multirow{7}{*}{ 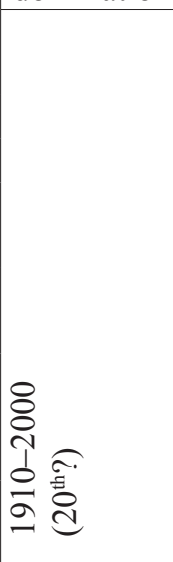 } & \multirow{7}{*}{$\begin{array}{l}\sum_{1}^{n} \\
0 \\
0 \\
0 \\
0 \\
0 \\
0 \\
0\end{array}$} & \multirow{7}{*}{ 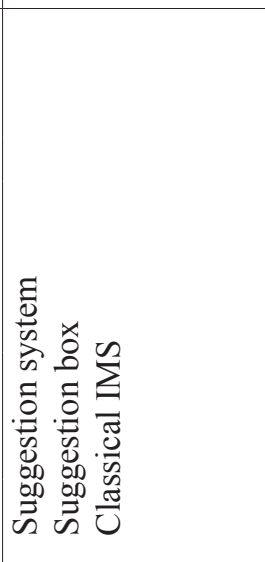 } & Functions & $\begin{array}{l}\text { Focus on idea collection, less to evaluation and } \\
\text { development }\end{array}$ \\
\hline & & & Type of focus & Unfocused process \\
\hline & & & Idea creators (general) & Internal \\
\hline & & & Realization & $\begin{array}{l}\text { Suggestion e-mail } \\
\text { Real life activities }\end{array}$ \\
\hline & & & $\begin{array}{l}\text { Commercially available } \\
\text { IMS price }\end{array}$ & 4-49,50 USD / month \\
\hline & & & - & $\begin{array}{l}\text { Lack of feedback } \\
\text { In short term become ineffective } \\
\text { Hard to find idea addresses }\end{array}$ \\
\hline & & & + & $\begin{array}{l}\text { Not expensive } \\
\text { Easy to use }\end{array}$ \\
\hline \multirow[b]{7}{*}{ 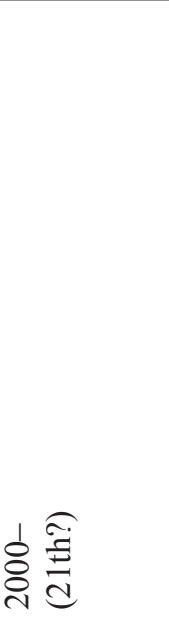 } & \multirow{7}{*}{ 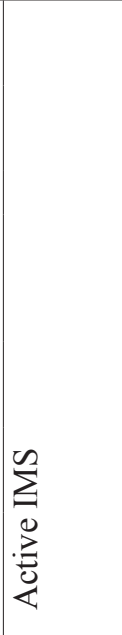 } & \multirow{7}{*}{$\sum_{i}^{\infty} \sum_{\substack{0 \\
0}}^{\infty}$} & Functions & $\begin{array}{l}\text { Combination of processes of idea generation, } \\
\text { evaluation, development }\end{array}$ \\
\hline & & & Type of focus & $\begin{array}{l}\text { Focused process (general) / could be also } \\
\text { unfocused }\end{array}$ \\
\hline & & & Idea creators (general) & Internal, external \\
\hline & & & Realization & $\begin{array}{l}\text { Complex system in real life with or/and virtual } \\
\text { elements } \\
\text { Web-based platform }\end{array}$ \\
\hline & & & $\begin{array}{l}\text { Commercially available } \\
\text { IMS price }\end{array}$ & 14,95 USD - $250 \mathrm{USD} /$ month \\
\hline & & & - & $\begin{array}{l}\text { Complicated } \\
\text { Higher costs than passive IMS }\end{array}$ \\
\hline & & & + & $\begin{array}{l}\text { Quick feedback } \\
\text { Some of all idea management procedures are } \\
\text { automation }\end{array}$ \\
\hline
\end{tabular}

Source: compiled by the authors

According to Perez, Larringa and Curry (2013) active IMS manage the innovation lifecycle from the moment of invention until ideas are implemented in the market (including idea generation, analysis, enrichment, selection, development, implementation) and Zejnilovic, Oliveira and Veloso (2012) declared that IMS are instruments to encourage employee involvement in innovation also Sadriev and Pratchenko (2014) revealed that IMS allows to build up and to direct purposefully the innovation processes, a an integral part of the idea management. Authors conclude that IMS is tool, instrument, system which supports innovation process.

Active IMS frequently are connected with virtual tools and opportunities. For example, Bansemir and Neyer (2009) described that IMS can foster the idea management in software application, also Westerski, Dalamagas, Iglesias (2013) concluded that IMS could be also web application which provides open innovation conditions with crowdsourcing to develop product/service ideas. IMS - idea generation, improvement, selection, realization, collocation. Furthermore Baez and Convertino (2012) noticed that IMS is an emerging class of collaborative software for business organizations or local geographic communities, in these systems users generate, share, judge, refine, select ideas as a part of a grassroots process. Also Summa (2004) considered that IMS could be connected with IT describing IMS as process of store ideas and relevant documentation in database giving the organization wide access to the information and transfers ideas and their utiliza- 
tion effectively to every location Authors conclude that term could be used to describe software applications which provides IM functionalities. These systems are available on PCs, smartphones and tablets, where previously defined audience can create, evaluate and develop ideas.

\subsection{IM and IMS focuses}

Research results represents that IM and IMS are systematic and manageable objects. $100 \%$ of all analysed literature sources revealed that these objects are manageable. Very interesting aspect that only 2 sources describes IM as unstructured process, but both sources are developed before 1990, that is Galbraith (1982) research "Design the Innovating organization" and Applegate (1986) study "Idea management in organization planning (brainstorming, strategy)".

\subsection{Created term definitions and relation between terms}

Result revels that IM and IMS terms are connected and both used as descriptive parts of innovation process. IM is more wider and uncertain term, but IMS is more determined sub term of IM. Relation among the terms see in Figure 3.

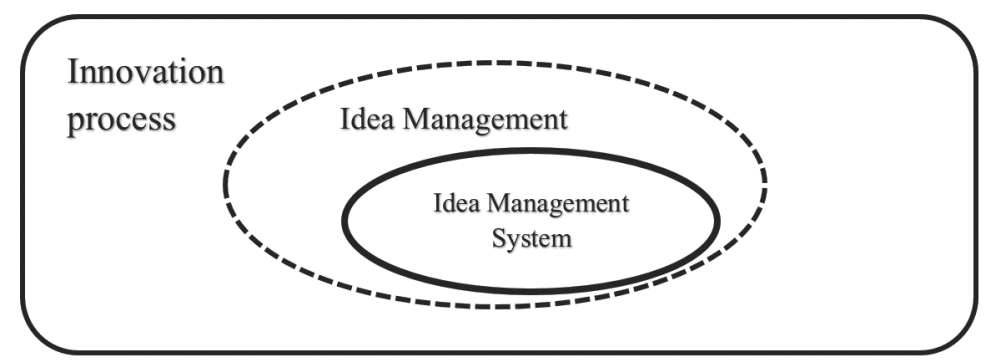

Figure 3. Relation between innovation process, IM and IMS terms

Source: compiled by the authors

Results probe that IM could be defined as - systematic, manageable process of idea generation, evaluation and development, but the IMS as a tool, tool kit or complex system which provides systematic, manageable process of idea generation, evaluation and development. See in Table 3.

Table 3. Created definitions and application questions

\begin{tabular}{|l|l|l|}
\hline \multicolumn{1}{|c|}{ Term } & \multicolumn{1}{|c|}{ Definition } & \multicolumn{1}{|c|}{ Application question } \\
\hline IM & $\begin{array}{l}\text { Systematic, manageable process of idea generation, evaluation and } \\
\text { development }\end{array}$ & What? \\
\hline IMS & $\begin{array}{l}\text { Tool, tool kit or complex system which provides systematic, } \\
\text { manageable process of idea generation, evaluation and development }\end{array}$ & How? With what kind of tools? \\
\hline
\end{tabular}

Source: compiled by the authors

For example, IM is systematic and manageable process of idea generation, evaluation and development in organizations, but IMS is tool or complex system which provides IM, for example, IMS developed by scientists like SIM (described in Rowbotham, Bohlin, 1996), SCIMAX (described in Azrolan, Pavlins, 1998), IDeM (described in Bothos, Apostolou, Mentzas, 2008; 2009), Creations (described in Flynn et al., 2003). Several tools can be identified from IT perspective - commercially available IMS in internet as AKIVA researched by (2002), Imaginatik's researched by Gamlin, Yourd and Patrick (2007), Webstorm, Idea Central, CogniStreamer researched by Bansemir and Neyer (2009), which foster the idea management in software application Many well-known companies use different IMS to involve their relation between clients and 
employees, according to Roebuck (2011) for example, Adidas, Henkel, IBM, Bombardier, Cisco, Dell, 3M, Spar, Detecon, Google, Lego, Toyota, BMW, Melitta, Microsoft, Starbucks, Ideo, Samsung, Rocher, Tchibo. According to trend that frequently IMS are identified as IT tools, authors suggest to create additional research about these tools - terms, classification and evaluation. Previous research had also revealed the topicality of this task, because it has been highlighted as a research gap that there is no additional and deep researches about commercially available web based IMS. Authors suggest that not only commercially available web based IMS should be researched, but also private and non-commercial web based IMS to create more holistic research in this context.

Authors suggest that created definitions should be discussed with IM / IMS researchers and practitioners with the aim to evaluate them. Authors hope that this paper will stimulate scientific discussions about IM and IMS.

Authors also recommend in the future research to conduct empirical research to research if on theoretical bases created definitions could be applied to practise, in this case authors suppose that the most appropriate method could be case studies of IM and IMS application from different sectors.

\subsection{Regional identity aspects}

Exploring literature sources by their country of origin (certain by the main author) has disclosed the regions with the highest level of IM and IMS literature sources which highlights regional scientific interest and spread. Based on United Nations (2012) created country classification by regions mainly IM and IMS is researched in Europe (63\% of all researched sources) and Northern America (24\%), but it is should be noticed that there is no researches from Latin America and the Caribbean, Oceania, Sub-Saharan Africa. Data analyses highlights that the most of the sources are created by the scientists form USA (22\%), Germany (15\%), Spain (13\%), Sweden (7\%), Netherland (6\%) and Denmark (6\%). All summary is presented in Table 4.

Table 4. Count of literature sources by regions

\begin{tabular}{|c|c|c|c|c|c|c|c|c|c|c|c|c|c|c|c|c|c|c|c|}
\hline & Africa & & Asia & & \multicolumn{13}{|c|}{ Europe } & \multicolumn{2}{|l|}{ NA } \\
\hline & $\begin{array}{l}0 \\
0 \\
0 \\
0 \\
\dot{0}\end{array}$ & $\stackrel{\Xi}{\stackrel{\Xi}{\Xi}}$ & $\begin{array}{l}\stackrel{\Xi}{\Xi} \\
\text { U }\end{array}$ & 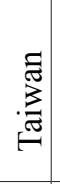 & 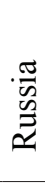 & $\begin{array}{l}\widehat{\Xi} \\
\text { हूँ }\end{array}$ & $\begin{array}{l}\text { : } \\
\stackrel{7}{2}\end{array}$ & 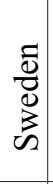 & 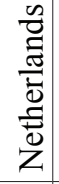 & $\begin{array}{l}\text { 플 } \\
\text { : } \\
\text { D. }\end{array}$ & $\begin{array}{l}\tilde{U} \\
\mathbb{\Xi} \\
\tilde{\Xi}\end{array}$ & $\breve{s}$ & $\begin{array}{c}\vec{\Xi} \\
\vec{\Xi} \\
\vec{\Xi} \\
\text { I }\end{array}$ & $\begin{array}{l}\text { ते } \\
\text { : } \\
\text { Z }\end{array}$ & 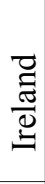 & $\begin{array}{l}\frac{\pi}{\tilde{0}} \\
\frac{\overrightarrow{0}}{\tilde{\omega}}\end{array}$ & 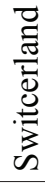 & $\tilde{2}$ & $\begin{array}{l}\frac{\pi}{\tilde{J}} \\
\text { Uే } \\
\text { Uే }\end{array}$ \\
\hline $\mathrm{Ct}$. & 1 & 3 & 2 & 1 & 1 & 10 & 9 & 5 & 4 & 4 & 3 & 4 & 4 & 4 & 1 & 1 & 1 & 17 & 1 \\
\hline Sum. & 1 & & 7 & & & & & & & & 44 & & & & & & & 18 & \\
\hline
\end{tabular}

Source: compiled by the authors

Deeper evaluation of data in Europe on sub-region level shows that, there is no literature sources from Eastern Europe, Northern Europe leads with 16 sources followed by Western Europe (15 sources) and Southern Europe (13 sources). Research reveals that in these sub-regions literature sources about IM and IMS are created equally, so also scientific interest level in these region could be evaluated as similar.

There are some regions where IM and IMS are more widely researched, but there isn't important differences between used definitions of IM and IMS in different regions. Authors suppose that regional identity aspect of perception of these terms in different sectors should be researched, that could reveal regional identity aspects empirically, because this research only party and theoretically reveal scientific views on these terms in different regions.

But authors had conduct additional research to explore the most influencing regions in IM and IMS research. According to research data in databases - Google Scholar (2015) and Scopus (2015) - authors have revealed the most influential authors in IM and IMS literature. Results of the research represents that the most cited authors about IM and IMS are Vandenbosch (USA), Bothos (Greece), Westerski (Spain), Brem 
(Germany), Flynn (Ireland), Sandstrom (Sweden). Authors conclude that the most influential regions in this context are Europe and USA. It should be noticed that research results also revealed that the most frequent used IM definition is Vandenbosch (USA) used definition of IM.

\section{Conclusions}

In this paper authors have discussed terms IM and IMS to fill the research gap- there is no united view on the terms IM and IMS and there is no specialized researches about these terms, as well, in the literature of IM they are not broadly discussed. Originality of the paper - article gives overview about the terms of IM and IMS and based on the research define these terms, so in all regions could be used common terminology and definitions.

The research highlights that in the literature there are diversity of IM and IMS terms definitions. The results of the research revealed that the terms of IM has not fundamentally changed over the time, but IMS have had transformation from "passive" to "active" IMS in millennium.

Result revels that IM and IMS terms are connected and both used as descriptive parts of innovation process. IM is more wider and uncertain term, but IMS is more determined sub term of IM. The object of these terms more often are described as systematic and manageable. Results probe that fundamentally IM definition could be-systematic, manageable process of idea generation, evaluation and development, but the IMS - tool, tool kit or complex system which provides systematic, manageable process of idea generation, evaluation and development.

There are some regions where IM and IMS are more widely researched, but there isn't important characteristics of differences term definition in different regions. Results of the research represents that the most cited authors about IM and IMS are Vandenbosch (USA), Bothos (Greece), Westerski (Spain), Brem (Germany), Flynn (Ireland), Sandstrom (Sweden). Authors conclude that the most influential regions in this context are Europe and USA.

Authors have developed several recommendations for future work, but the 3 main are:

- Authors suggest that created definitions should be discussed with IM / IMS researchers and practitioners with the aim to evaluate them.

- According to trend that frequently IMS are identified as IT tools, authors suggest to create additional research about these tools-terms, classification and evaluation. Authors suggest that there should be researched not only commercially available web based IMS, but also private and non-commercial web based IMS to create more holistic research in this context.

- Authors suppose that regional identity aspect of perception of these terms in different sectors should be researched, that could reveal regional identity aspects empirically, because this research only party and theoretically reveal scientific views on these terms in different regions.

\section{References}

Aagaard, A. (2012). Idea Management in support of Pharmaceutical Front End of Innovation. International Journal of Technology, Policy and Management, Vol. 12, No. 4, p. 373-386.

Applegate, L. M. (1986). Idea management in organization planning (brainstorming, strategy). Dissertation, University of Arizona: Arizona.

Azrolan, N., Pavlins, M. S. (1998). Idea management: Restructuring technology-based research to help achieve corporate goals. Drug News Perspect, Vol. 11, No. 3, p. 180-184.

Baez, M., Convertino, G. (2012). Innovation Cockpit: A Dashboard for Faciliators in Idea Management. ACM 2012 conference proceedings of the international conference in Seattle, Washington, USA. NY: ACM, p. 47-48.

Bailey, B. P., Horvitz, E. (2010). What's Your Idea? A Case Study of a Grassroots Innovation Pipeline within a Large Software Company. CHI2010 proceedings on the 28th annual CHI conference on human factors in computing systems in Atlanta, USA, 2010. NY: ACM, p. 2065-2074. 
Bakker, H., Boersma, K., Oreel, S. (2006). Creativity (Ideas) Management in Industrial R\&D Organizations: A Crea - Political Process Model and an Empirical Illustration of Corus RD\&T. Creativity and Innovation Management, Vol. 15, No. 3. p. 296-309.

Bansemir, B., Neyer, A. K. (2009). From idea management systems to interactive innovation management systems: Designing for interaction and knowledge exchange. Wirtschaft informatik Proceedings, Vol. 1, No. 1, p. 860-870.

Barczak, G., Griffin, A., Kahn, B. K. (2009). PERSPECTIVE: Trends and Drivers of Success in NPD Practices: Results of the 2003 PDMA Best Practices Study. Journal of Product Innovation Management, Vol. 26, No. 1, p. 3-23.

Bassiti, L., Ajhoun, R. (2013). Toward an Innovation Management Framework: A Life-cycle Model with an Idea Management focus. International Journal of Innovation, Management and Technology, Vol. 4, No. 6, p. 551-559.

Bettoni, M., Bernhard, W., Eggs, C., Schiller, G. (2010). Idea Management by Role Based Networked Learning. 11th European conference on knowledge management proceedings of the international conference. London: Academic Publishing Limited, p. 107-116.

Bjork, J., Magnusson, M. (2009). Where Do Good Innovation Ideas Come From? Exploring the Influence of Network Connectivity on Innovation Idea Quality. Journal of Product Innovation Management, Vol. 26, No. 1, p. $662-670$.

Boden, M. A. (1998). Creativity and artificial intelligence. Artificial Intelligence, Vol. 103, No. 1, p. 347-356.

Boeddrich, H. J. (2004). Ideas in the Workplace: A New Approach Towards Organizing the Fuzzy Front End of the Innovation Process. Creativity and Innovation Management, Vol. 13, No. 4, p. 274-285.

Bothos, E., Apostolou, D., Mentzas, G. (2008). A Collaborative Information Aggregation System for Idea Management. Conference on Internet and Web Applications and Sevices proceedings of the international conference in Athens. Athens: IEEE, p. 289-296.

Bothos, E., Apostolou, D., Mentzas, G. (2009). Collective intelligence for idea management with Internet-based information aggregation markets. Internet Research, Vol. 19, No. 1, p. 26-41.

Bothos, E., Apostoulou, D., Mentzas, G. (2012). Collective intelligence with web-based information aggregation markets: The role of market faciliation in idea management. Experts Systems with Applications, Vol. 39, No. 1, p. 1333-1345.

Brem, A., Voigt, K. I. (2007). Innovation management in emerging technology ventures - the concept of an integrated idea management. Journal of Technology, Policy and Management, Vol. 7, No. 3, p. 304-321.

Brem, A., Voigt, K. I. (2009). Integration of market pull and technology push in the corporate front end and innovation management- Insights from the German software industry. Technovation, Vol. 29, No. 1, p. 351-367.

Brinkmann, E., Heidack C. (1984). Unternehmenssicherung durch Ideenmanagement. Freiburg: Haufe.

Conert, C., Schenk, M. (2000). Stand und Zukunft des betrieblichen Vorschlagswesens in Deutschland. In: D. Frey, S. Schulz-Hardt (eds.). Vom Vorschlagwesen zum Ideenmanagement. Gottingen: Verlag fur Angewandte Psychologie, p. $65-89$.

Coughlan, T., Johnson, P. (2008). Idea Management in Creative Lives. Conference on Human Factors in Computing Systems proceedings of the international conference. NY: ACM, p. 3081-3086.

Day, G. S., Gold, B., Kuczmarski, T. D. (1994). Significant Issues for the Future of Product Innovation. Journal of Product Innovation Management, Vol. 11, No. 1, p. 69-75.

Deichmann, D. (2012). Idea Management: Perspectives from Leadership, Learning, and Network Theory. Dissertation. Netherland: ERIM.

Dickinson, Z. C. (1932). Suggestions from workers: Schemes and problems. Quarterly Journal of Economics, Vol. 46, No. 4, p. 617-643.

Fairbank, J. F., Williams, S. D. (2001). Motivating creativity and enhancing innovation through employee suggestion system technology. Creativity \& Innovation Management, Vol. 10, No. 2, p. 68-74.

Flynn, M., Dooley, L., Sullivan, D., Cormican, K. (2003). Idea management for organizational innovation. International Journal of Innovation Management, Vol. 7, No. 4, p. 1-26.

Fritz, M. (2002). Idea management enabler. EContent, Vol. 25, No. 8, p. 50.

Galbraith, J. R. (1982). Designing the innovating organization. Organizational Dynamics, Vol. 10, No. 3, p. 5-25.

Gamlin, J. N., Yourd, R., Patric, V. (2007). Unlock creativity with "active" idea management. Research Technology Manageent, Vol. 50, No. 1, p. 13-16.

Gish, L. (2011). Experience with idea promoting initiatives: why they don't always work. 18th Conference on Engineering Design: Impacting Society through Engineering Design proceedings of the international conference. Copenhagen: Design Society, p. 83-92.

Glassmann, B. S. (2009). Improving idea generation and idea management in order to better manage the fuzzy front end of innovation. Lafayette: Prude University.

Goyal, A., Sampath, K. (2007). Institutionalizing innovation: look to employees for the next great idea. Ivey Business Journal, Vol. 71, No. 8, p. 1-5.

Green, S. G., Bean, S. A., Snavely, B. K. (1983). Idea management in R\&D as a human information processing analog. Human Systems Management, Vol. 4, No. 2, p. 98-112. 
Hrastinski, S., Kviselius, N. Z. (2010). A review of technologies for open innovation: Characterastics and future trends. Annual Hawaii International Conference on System Sciences proceedings. Kohla: IEEE, p. 1-10.

INSEAD. (2014). The Global Innovation Index 2013. Available at: http://www.globalinnovationindex.org/content. aspx?page=gii-full-report-2013\#pdfopener [accessed: 21 April 2015].

Iversen, H., Kristensen, K., Liland, C. S., Berman, T., Enger, N., Losnedahl, T. (2009). Idea Management: A Life- cycle Perspective on Innovation. Available at: http://www.ict-21.ch/com-ict/IMG/pdf/39_IdeaManagement_Kjetil_Kristensen_FINAL.pdf [accessed: 10 May 2015].

Jensen, M. B., Johnson, B., Lorenz, E., Lundvall, B. A. (2007). Forms of knowledge and modes of innovation. Research Policy, Vol. 36, No. 5, p. 680-693.

Karanjikar, M. R. (2007). Funnel-reverse-funnel: the future model of idea management in new product development. Futures Research Quarterly, Vol. 23, No. 3, p. 21-26.

Khurana, A., Rosenthal, S. R. (1998). Toward holistic "front end" in new product development. Journal of Product Innovation Management, Vol. 15, No. 1, p. 55-74.

Klein, D., Lechner, U. (2010). Ideenmanagement im Rahmen von organisatorischem Wandel. MKWI 2010-IKT-gestutzte Unternehmens kommunikation proceedings. Gottingen: Universitatsverlag Gottingen, S. 1831-1842.

Lindross, M. (2006). Developing Front-End idea management and information processing. Working paper, No. 39, 6 March. Innovation Management Institute, Helsinki University of Technology.

Lower, M., Heller, J. E. (2014). PLM Reference Model for Integrated Idea and Innovation Management. Product Lifecycle Management for a Global Market, IFIP Advances in Information and Communication Technology, Vol. 442, No. 1, p. 257-266.

Lu, I. M., Mantei, M. M. (1991). Idea Management in a Shared Drawing Tool. The Second European Conference on Computer-Supported Cooperative Work proceedings of the international conference. Rotterdam: Springer Netherlands, p. 97-112.

Miecznik, B. (2013). Ideen Management. In: T. Able (ed.). Suchfeldbestimmung und Ideenbewertung: Methoden und Prozesse in den frühen Phasen des Innovationsprozesses. London: Springer-Gabler, p. 143-168.

Mikelsone, E., Liela, E. (2015). Literature Review of idea management: focuses and gaps. Working paper, No. 2, 15 May. BA School of Business and Finance.

Miķelsone, E. (2013). Virtuālie ideju menedžmenta produkti: izmantojums un iespējas Latvijā. Working paper, No. 1. Valmiera: Vidzemes Augstskola.

Moss, B., Beimborn, D., Wagner, H. T., Weitzel, T. (2011). The role of innovation governance and knowledge management for innovation success. The 44th Annual Hawaii International Conference on System Science proceedings. Kohla: IEEE, p. 1-10.

Nilsson, L., Elg, M., Bergman, B. (2002). Managing ideas for the development of new products. International Journal of Technology Management, Vol. 24, No. 5/6, p. 498-513.

Perez, A., Larrinaga, F., Curry, E. (2013). The Role of Linked Data and Semantic-Technologies for Sustainability Idea Management. In: S. Counsell (ed.). Software Engineering and Formal Methods. Berlin: Springer-Verlag, p. 306-312.

Poveda, G., Westerski, A., Iglesias, C. A. (2012). Application of Semantic Search in Idea Management Systems. Conference for Internet Technology Secured Transactions proceedings of the international conference in London. UK, London: IEEE, p. 230-236.

Reuter, V. G. (1977). Suggestion systems: Utilization, evaluation, and implementation. California Management Review, Vol. 19, No. 3, p. 78-89.

Robinson, A. G., Stern, S. (1998). Coorporate creativity: How innovation and improvement actually happen. San Francisco: Berrett-Koehler Publishers.

Roebuck, V. (2011). Idea Management: High-impact Strategies - What You Need to Know: Definitions, Adoptions, Impact, Benefits, Maturity, Vendors. Available at: http://www.scribd.com/doc/62871215/Idea-Management-Highimpact-Strategies-What-You-Need-to-Know-Definitions-Adoptions-Impact-Benefits-Maturity-Vendors [accessed: 21 May 2015].

Rose, A., Jensen, V. (2012). A literature review of idea management. The paper presented at the 9th Nord Design conference proceedings DS 71 of Nord Design, Aarlborg University, Denmark. 22-24 August. Available at: https:// www.designsociety.org/publication/35610/a_literature_review_of_idea_management [accessed: 10 April 2015].

Rowbotham, L., Bohlin, N. (1996). Structured Idea Management as a Value-Adding Process. Available at: http://www. adlittle.com/uploads/tx_extprism/1996_q2_31-36.pdf [accessed: 10 April 2015].

Saatcioglu, A. (2002). Using grounded inquiry to explore idea management for innovativeness. Paper presented at Academy of Management Proceedings. Available at: http://proceedings.aom.org/content/2002/1/C1.19.abstract [accessed: 10 May 2015].

Sandriev, A. R., Pratchenko, O. V. (2014). Idea management in the system of innovative management. Mediterranean Journal of Social Sciences, Vol. 5, No. 12, p. 155-158. 
Sandstrom, C., Bjork, J. (2010). Idea management systems for a changing innovation landscape. International Journal of Product Development, Vol. 11, No. 3/4, p. 310-324.

Selart, M., Johansen, S. T. (2011). Understanding the Role of Value - Focused Thinking in Idea Management. Creativity and Innovation Management, Vol. 20, No. 3, p. 196-206.

Shani, N., Divyapriya, P. (2011). A Role of Innovative Idea Management in HRM. International Journal of Management, Vol. 2, No. 1, p. 69-78.

Summa, A. (2004). Software tools to support innovation process - focuss on idea management. Working paper, No. 29 , 15 June. Innovation Management Institute, Helsinki University of Technology.

Tung, W. F., Yuan, S. T., Tsai, J. R. (2009). A custom collaboration service system for idea management of mobile phone design. Human Factors and Ergonomics in Manufacturing, Vol. 19, No. 5, p. 494-509.

United Nations. (2012). Classification of countries by major area and region of the world. Available at: http://esa. un.org/wpp/Excel-Data/country-classification.pdf [accessed: 10 May 2015].

Vagn, A. R., Clause, C., Gish, L. (2013). Towards a new perspective of managing ideas in front-end innovation as actor networks. The paper presented at the 63. International Conference on Engeneering design, 19-22 August, Seoul, Korea. Available at: http://orbit.dtu.dk/ws/files/58958235/ICED_13.pdf [accessed: 10 April 2015].

Van Dijk, C., Van den Ende, J. (2002). Suggestion systems: Transfering employees creativity into practicable ideas. $R \& D$ Management, Vol. 32, No. 5, p. 387-395.

Vandenbosch, B., Saatcioglu, A., Fay, S. (2006). Idea management: A systematic view. Journal of Management Studies, Vol. 43, No. 2, p. 259-288.

Voigt, K. I., Brem, A. (2006). Integrated Idea Management in Emerging Technology Ventures. IEEE International Conference on Management of Innovation and Technology proceedings of the international conference in Singapore, China. Singapore: IEEE, p. 211-215.

Westerski, A., Dalamagas, T., Iglesias, C. A. (2013). Classifying and comparing community innovation in Idea Management Systems. Decision Support Systems, Vol. 54, No. 1, p. 1316-1326.

Westerski, A., Iglesias, C. A., Nagle, T. (2011). The road from community ideas to organisational innovation: a life cycle survey of idea management systems. International Journal of Web Bases Communities, Vol. 7, No. 4, p. $493-506$.

Westerski, A., Iglesias, C. A., Rico, F. T. (2010). A model for integration and interlinking of idea management systems. Communications in Computer and Information Science, Vol. 108, No. 1, p. 183-194.

Wood, A. (2003). Managing Employees' Ideas From Where do Ideas Come? Journal for Quality \& Participation, Vol. 26, No. 2, p. 22-26.

Xie, L., Zhang, P. (2010). Idea Management System for Team Creation. Journal of Software, Vol. 5, No. 11, p. 11871194.

Zejnilovic, L., Oliveira, P., Veloso, F. (2012). Employees as User Innovators: An Empirical Investigation of an Idea Management System. SSRN Electronic Journal, Vol. 1, No. 1, p. 1-38.

Zhang, Q., Doll, W. (2001). The Fuzzy Front End and Success of New Product Development: A Casual Model. European Journal of Innovation Management, Vol. 4, No. 2, p. 95-112.

\title{
DISKUSIJA DÉLIDËJŲ VALDYMO IR IDËJŲ VALDYMO SISTEMU TERMIN Ų
}

\author{
Elīna Mikelsone, Elita Lielā \\ Baltijos akademijos Verslo ir finansų mokykla (Latvija)
}

\section{Santrauka}

Nors idejjų valdymas (IV) ir idejų valdymo sistemos (IVS) kaip moksliniai objektai tirti nuo 1982 metų, mokslinejje literatūroje vis dar esama spragų, atliekant tyrimus šia tematika ir vis dar nesutariama dèl vartojamų terminų tikslumo. Tyrimo tikslas - pateikti idejjų valdymo ir idejų valdymo sistemos apibrěžimus, remiantis apžvelgiama moksline literatūra. Tyrimo objektas - idejjų valdymo ir idejų valdymo sistemų apibrěžimai. Pagrindinis tyrimo metodas - mokslinès literatūros apžvalga ir analizè. Duomenys rinkti iš 70 
šaltinių, įskaitant mokslines publikacijas, konferencijų medžiagą, knygas ir t. t., kurie paskelbti per pastaruosius 33 metus, t. y. nuo 1982 metų sausio mėnesio iki 2015 metų vasario mėnesio, visose tyrimų srityse. Tyrimo rezultatai atskleidè, kad idejų valdymo apibrèžimai per pasirinką ir nagrinèjamą laikotarpi iš esmès nepasikeite, bet idẻjų valdymo sistemų apibrēžimai transformuoti iš ,pasyvių“ $\mathfrak{i}$, ,aktyvius“. Šių apibrèžimų objektas dažniau apibūdinamas kaip sistemingas ir valdomas. Rezultatai atskleidè, kad idèjų valdymas gali būti apibrèžtas kaip sistemingas, valdomas idèjų generavimo, vertinimo ir vystymo procesas, o idejų valdymo sistema - kaip priemonè, įrankių komplektas ar sudètinga sistema, kuri pateikia susistemintą, valdomą idèjų generavimo, vertinimo ir vystymo procesą. Tyrimų intensyvumas analizuojama tema kinta atsižvelgiant $\mathfrak{i}$ regioną, bet didelių regioninių skirtumų apibūdinant analizuojamus idèjų valdymo ar idèjų valdymo sistemos terminus nèra.

PAGRINDINIAI ŽODŽIAI: Idejų valdymas, Idejų valdymo sistemos, diskusija, literatūros apžvalga.

JEL KLASIFIKACIJA: M190; M150; M110 